\title{
Salinity-tolerant larvae of mosquito vectors in the tropical coast of Jaffna, Sri Lanka and the effect of salinity on the toxicity of Bacillus thuringiensis to Aedes aegypti larvae
}

\author{
Pavilupillai J Jude1, Tharmatha Tharmasegaram¹, Gobika Sivasubramaniyam², Meena Senthilnanthanan², \\ Selvam Kannathasan ${ }^{3}$, Selvarajah Raveendran ${ }^{4}$, Ranjan Ramasamy ${ }^{5^{*}}$ and Sinnathamby N Surendran ${ }^{{ }^{*}}$
}

\begin{abstract}
Background: Dengue, chikungunya, malaria, filariasis and Japanese encephalitis are common mosquito-borne diseases endemic to Sri Lanka. Aedes aegypti and Aedes albopictus, the major vectors of dengue, were recently shown to undergo pre-imaginal development in brackish water bodies in the island. A limited survey of selected coastal localities of the Jaffna district in northern Sri Lanka was carried out to identify mosquito species undergoing pre-imaginal development in brackish and saline waters. The effect of salinity on the toxicity of Bacillus thuringiensis israelensis larvicide to Ae. aegypti larvae at salinity levels naturally tolerated by Ae. aegypti was examined.

Methods: Larvae collected at the selected sites along the Jaffna coast were identified and salinity of habitat water determined in the laboratory. The $L C_{50}$ and $L C_{90}$ of $B$. thuringiensis toxin, the active ingredient of a commercial formulation of the larvicide BACTIVEC ${ }^{\circledR}$, were determined with Ae. aegypti larvae. Bioassays were also carried out at salinities varying from 0 to 18 ppt to determine the toxicity of Bacillus thuringiensis to fresh and brackish water-derived larvae of Ae. aegypti.

Results: Larvae of four Anopheles, two Aedes, one Culex and one Lutzia species were collected from brackish and saline sites with salinity in the range 2 to 68 ppt. The $L C_{50}$ and $L C_{90}$ of $B$. thuringiensis toxin for the second instar larvae of Ae. aegypti in fresh water were $0.006 \mathrm{ppm}$ and $0.013 \mathrm{ppm}$ respectively, with corresponding values for brackish water populations of 0.008 and $0.012 \mathrm{ppm}$ respectively. One hundred percent survival of second instar fresh water and brackish water-derived Ae. aegypti larvae was recorded at salinity up to 10 and 12 ppt and 100\% mortality at 16 and 18 ppt, yielding an $\mathrm{LC}_{50}$ for salinity of $13.9 \mathrm{ppt}$ and $15.4 \mathrm{ppt}$ at $24 \mathrm{~h}$ post-treatment respectively for the two populations. Statistical analysis showed significantly reduced toxicity of $B$. thuringiensis to fresh and brackish water-derived Ae. aegypti larvae at high salinities.

Conclusion: A variety of mosquito vectors of human diseases undergo pre-imaginal development in brackish or saline waters in coastal areas of the Jaffna district in northern Sri Lanka. Salinity has a small but significant negative impact on the toxicity of $B$. thuringiensis toxin to Ae. aegypti larvae at salinity levels where Ae. aegypti larvae are found in the environment. This has implications for the use of $B$. thuringiensis toxin as a larvicide in brackish waters.
\end{abstract}

Keywords: Aedes aegypti, Bacillus thuringiensis, Dengue, Jaffna, Mosquito vectors, Salinity, Sri Lanka

\footnotetext{
* Correspondence: ranjanramasamy@yahoo.co.uk; noble@jfn.ac.lk

${ }^{5}$ Institute of Health Sciences, Universiti Brunei Darussalam, Gadong, BE 1410, Brunei Darussalam

'Department of Zoology, Faculty of Science, University of Jaffna, Jaffna 40000, Sri Lanka

Full list of author information is available at the end of the article
} 


\section{Background}

Aedes aegypti (Linnaeus) and Ae. albopictus Skuse are the established vectors of dengue and chikungunya in populated areas worldwide [1-3]. Dengue is of major public health concern in many tropical and semi-tropical countries [1]. In the tropical Jaffna district of northern Sri Lanka, there were 400 cases of dengue with 4 deaths in 2011 [4] and an epidemic of chikungunya in the period 2006 to 2007 [5]. Malaria has been historically endemic in Sri Lanka but its incidence has drastically declined in recent years [6]. Other important mosquitoborne diseases prevalent in Sri Lanka are filariasis [7] and Japanese encephalitis (JE) [8].

Larval source reduction is the primary means of controlling dengue in Sri Lanka and worldwide [1]. A commercial liquid formulation (BACTIVEC ${ }^{\circledR}$ ) that contains spores and toxin crystals of Bacillus thuringiensis israelensis $\mathrm{H}-14$ is used in Sri Lanka by the Ministry of Health as a larvicide for the control of dengue vectors. Although various commercial formulations of $B$. thuringiensis toxin are widely used in many countries for control of different mosquito vectors [9], it is used only for Aedes control in Sri Lanka.

Recent studies in some coastal areas of Jaffna and the eastern Batticaloa districts of Sri Lanka show that both Ae. aegypti and Ae. albopictus naturally undergo preimaginal development in brackish water collections in the environment [10] including frequently-used domestic wells [11]. Water with $<0.5$ ppt or parts per thousand, 0.5-30 ppt and $>30$ ppt salt are termed fresh, brackish, and saline respectively as in previous studies [10]. Such brackish water habitats may constitute unappreciated sources of dengue vectors in tropical coasts worldwide [12]. The over-exploitation of ground water from aquifers for agricultural, domestic and industrial use, has led to increasing salinisation of groundwater in the Jaffna peninsula [13]. In this context, a limited larval survey was performed in selected coastal localities in the Jaffna district to record mosquito species undergoing preimaginal development in brackish and saline waters. The impact of salinity levels that Ae. aegypti larvae tolerate in their habitats on the toxicity of a commercial formulation of $B$. thuringiensis israelensis $\mathrm{H}-14$ toxin $\left(\mathrm{BACTIVEC}^{\mathrm{R}}\right)$ to Ae. aegypti larvae was also examined.

\section{Methods}

\section{Mosquito collections}

Mosquito larvae were collected at five coastal locations viz. Sarasalai, Kurunagar, Pannai bridge, Delft island and Nainativu island (Figure 1A-F) in the Jaffna district during the period from August 2011 to May 2012. Kurunagar was selected based on the previous reports $[10,11]$ that pre-imaginal stages of dengue vectors are found in brackish water in the area. Two populated islands off the
Jaffna coast viz. Delft and Nainativu were chosen randomly for studying islands. Additionally, two readily accessible mangrove locations viz. at Sarasalai and Pannai bridge were selected from four other mangrove sites in the district. Collections were carried out monthly at each site. Three hundred and fifty $\mathrm{ml}$ capacity dippers were used to collect larvae from disused boats, pits, domestic wells, ponds and stagnant water bodies that were considered to be potentially brackish (except during the monsoon season) along the coast. Five dips per collection site on average were performed from 0800 to $1000 \mathrm{~h}$. The collected larvae in water were brought to the Zoology Laboratory of the University of Jaffna at Thirunelvely, and the salinity of the water determined with a refractorsalinometer (Atago, Japan). Larvae were reared to adulthood in the respective collected water as described previously [10]. Initially for rearing purposes, Aedes, Culex and Lutiza larvae and later emergent adults of all mosquito species were identified using standard keys [14-16].

\section{Determination of $\mathrm{LC}_{50}$ and $\mathrm{LC}_{90}$ of $\mathrm{BACTIVEC}^{\circledR}$ against Ae. aegypti}

From a commercial formulation of BACTIVEC $^{\circledR}$ (obtained from Medical Officer of Health, Nallur), test solutions containing $0.005,0.006,0.013,0.018,0.025$, $0.031,0.063$ and $0.126 \mathrm{ppm}$ of $B$. thuringiensisis $\mathrm{H}-14$ toxin (the ppm of active ingredient from the specified concentration of $0.6 \%$ in the commercial formulation) were prepared by serial dilution in a final volume of 100 $\mathrm{ml}$ tap water. Ten second instar larvae of Ae. aegypti from a laboratory colony that was derived from eggs deposited in fresh water ovitraps were placed in $100 \mathrm{ml}$ test solution in $150 \mathrm{ml}$ capacity plastic cups. Three replicates were run in parallel at each tested concentration. One hundred $\mathrm{ml}$ of the same tap water without BACTI$\mathrm{VEC}^{\circledR}$ was used as a control. Mortality of the larvae was determined $24 \mathrm{~h}$ after treatment.

A similar experiment was conducted with Ae. aegypti larvae collected from a brackish water site in Kurunagar with 10 ppt salinity and then used to establish a shortterm laboratory colony with pre-imaginal development allowed to occur in tap water containing $10 \mathrm{ppt}$ salt. Second instar larvae from the second generation of the colony were used in the experiment. Water of $10 \mathrm{ppt}$ salinity was used in place of tap water for the experiment on brackish water-derived larvae.

\section{Evaluation of the toxicity of $B$. thuringiensis at different salinity levels}

Solutions with salinity of $0,2,4,6,8,10,12,14$ and 16 ppt solutions were prepared by adding tap water to sea water as described previously [10]. Second instar larvae of Ae. aegypti from a laboratory colony derived from eggs oviposited in fresh water were used for this experiment. 

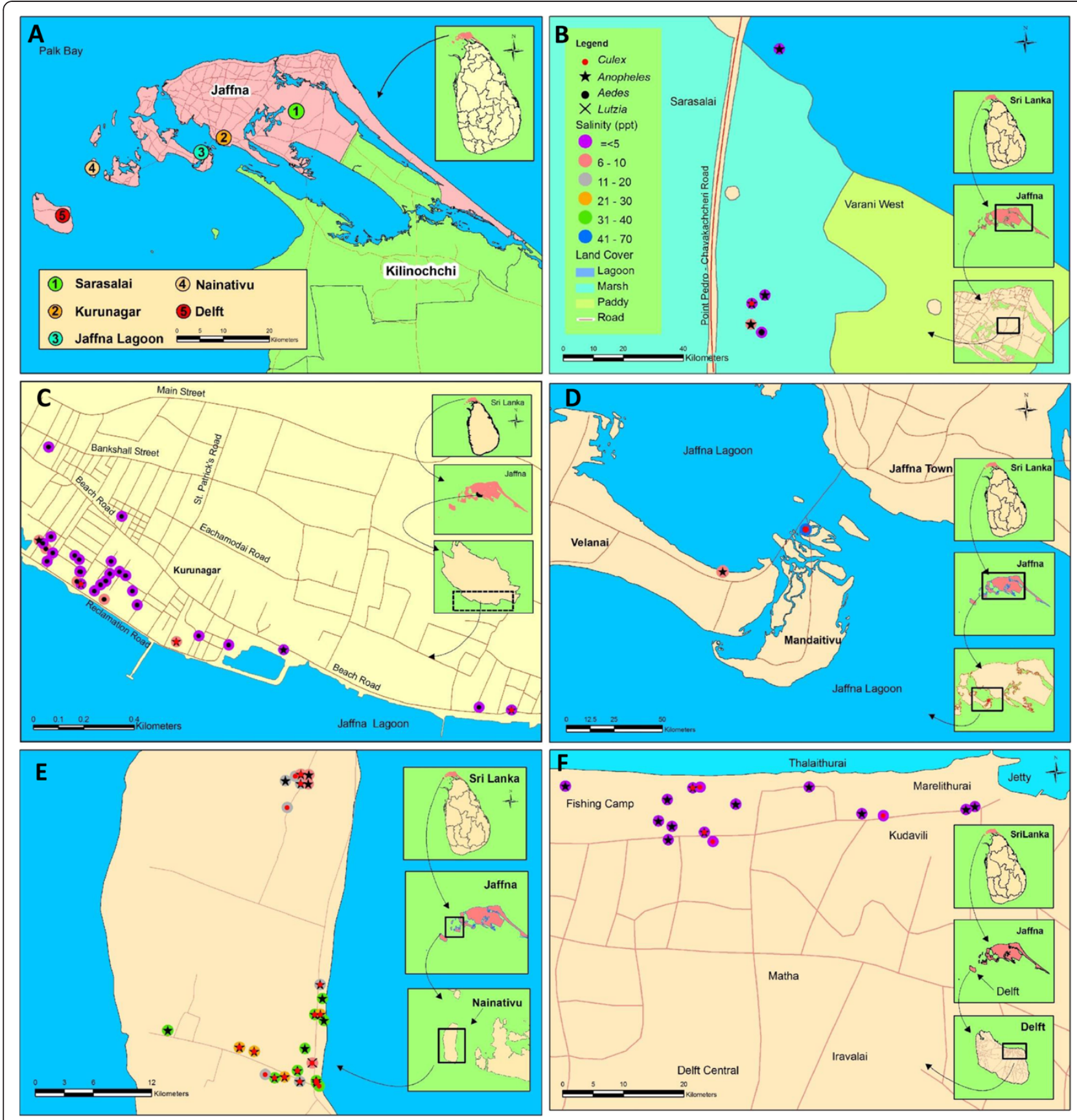

Figure 1 Map showing larval collection sites in the Jaffna district of Sri Lanka. A. Jaffna district. B. Sarasalai mangrove marsh. C. Kurunagar coast. D. Pannai bridge mangrove marsh. E. Nainativu island. F. Delft island.

Ten larvae were introduced into each concentration of test solution in $100 \mathrm{ml}$ tap water in $150 \mathrm{ml}$ capacity plastic cups. Tap water alone was used as control. In one set of tests, $0.018 \mathrm{ppm}$ of $B$. thuringiensis toxin (the lowest tested concentration that was found to cause $100 \%$ mortality among second instar larvae of fresh and brackish waterderived Ae. aegypti) was introduced into all test solutions of varying salinity. Test solutions without BACTIVEC ${ }^{\circledR}$ were used in a second set of tests. Three replicates were run in parallel at each salinity level for tests with and without BACTIVEC ${ }^{\circledR}$. Mean larval mortality was determined at 24,48 and $72 \mathrm{~h}$ post-treatment. Larvae were fed twice a day with powdered fish meal pellet for the duration of the experiments. A similar experiment at salinities of $0,2,4,6$, 8, 10, 12, 16 and 18 ppt was conducted with brackish water-derived Ae. aegypti larvae. Mortality in second instar larvae was determined at 24, 48 and $72 \mathrm{~h}$ post-treatment with and without BACTIVEC ${ }^{\circledR}$. 


\section{Statistical analysis}

The required $\mathrm{LC}_{50}$ and $\mathrm{LC}_{90}$ values with $95 \%$ confidence intervals were determined by Probit analysis. The toxicity of $B$. thuringiensis at different salinity levels for each time interval was determined by a two-way ANOVA. The statistical significance of differential survival of fresh water and brackish water-derived Ae. aegypti larvae in the presence of BACTIVEC ${ }^{\circledR}$ at the salinity levels of $10,12,14$ and 16 ppt was determined using the Student's t-test. All analyses were done using Minitab statistical software (Minitab Inc, PA, USA).

\section{Results}

Larvae of four Anopheles, two Aedes, one Culex and one Lutzia species were collected from brackish and saline sites with salinity in the range of 2 to 68 ppt. Details of the collected larvae and their habitats are presented in Table 1 . The $\mathrm{LC}_{50}$ and $\mathrm{LC}_{90}$ of $B$. thuringiensis for the

Table 1 Brackish water breeding mosquitoes in Jaffna district

\begin{tabular}{|c|c|c|c|c|c|c|}
\hline Species & $\begin{array}{l}\text { Transmitted diseases/ } \\
\text { medical significance }\end{array}$ & $\begin{array}{l}\text { Location of } \\
\text { larval } \\
\text { collection }\end{array}$ & $\begin{array}{l}\text { Period of } \\
\text { larval } \\
\text { collection }\end{array}$ & $\begin{array}{l}\text { Nature of habitat } \\
\text { (numbers of sites } \\
\text { with larvae) }\end{array}$ & $\begin{array}{l}\text { Average larval } \\
\text { number per site in } \\
\text { 350ml/ dip }\end{array}$ & $\begin{array}{l}\text { Salinity range of brackish } \\
\text { water habitats with } \\
\text { larvae (ppt) }\end{array}$ \\
\hline \multirow[t]{2}{*}{$\begin{array}{l}\text { Aedes } \\
\text { aegypti }\end{array}$} & \multirow[t]{2}{*}{ Dengue, Chikungunya } & Kurunagar & $\begin{array}{l}2011 \\
\text { Sep - } 2012 \text { May }\end{array}$ & Used well (27) & 6 & $2-9$ \\
\hline & & Kurunagar & 2011 Sep & Barrel (1) & 35 & 10 \\
\hline \multirow[t]{2}{*}{$\begin{array}{l}\text { Aedes } \\
\text { albopictus }\end{array}$} & \multirow[t]{2}{*}{ Dengue, Chikungunya } & Sarasalai & 2012 Jan & $\begin{array}{l}\text { Tube near brackish } \\
\text { water mangrove } \\
\text { marsh (1) }\end{array}$ & 10 & 4 \\
\hline & & Sarasalai & 2012 Jan & $\begin{array}{l}\text { Battery box in brackish } \\
\text { water mangrove } \\
\text { marsh (1) }\end{array}$ & 8 & 4 \\
\hline \multirow[t]{6}{*}{$\begin{array}{l}\text { Anopheles } \\
\text { subpictus }\end{array}$} & \multirow[t]{6}{*}{ Malaria } & Delft & $\begin{array}{l}2012 \\
\text { Feb-April }\end{array}$ & Pond (2) & 14 & $2-6$ \\
\hline & & Nainativu & 2012 April & Used well (20) & 17 & $4-39$ \\
\hline & & Passaiyoor & 2011 Aug & Disused boats (2) & 4 & $15-18$ \\
\hline & & Kurunagar & 2011 Sep & Used well (3) & 7 & $2-6$ \\
\hline & & Sarasalai & 2012 Jan & $\begin{array}{l}\text { Pit in brackish water } \\
\text { mangrove marsh (2) }\end{array}$ & 11 & $10-12$ \\
\hline & & $\begin{array}{l}\text { Pannai } \\
\text { bridge }\end{array}$ & 2012 May & $\begin{array}{l}\text { Brackish water } \\
\text { mangrove marsh (1) }\end{array}$ & 3 & 10 \\
\hline \multirow{3}{*}{$\begin{array}{l}\text { Anopheles } \\
\text { barbirostris }\end{array}$} & \multirow{3}{*}{ Malaria } & Delft & 2012 April & Used well (3) & 4 & $5-6$ \\
\hline & & Sarasalai & 2012 Jan & $\begin{array}{l}\text { Pit near brackish water } \\
\text { mangrove marsh (1) }\end{array}$ & 2 & 4 \\
\hline & & Nainativu & 2012 April & Used well (1) & 3 & 15 \\
\hline $\begin{array}{l}\text { Anopheles } \\
\text { varuna }\end{array}$ & Malaria & Delft & 2012 Jan-April & Used well (11) & 4 & $2-4$ \\
\hline \multirow{2}{*}{$\begin{array}{l}\text { Anopheles } \\
\text { culicifacies }\end{array}$} & \multirow[t]{2}{*}{ Malaria } & Delft & 2012 Jan-April & Used well (3) & 3 & $2-4$ \\
\hline & & Sarasalai & 2012 Jan & $\begin{array}{l}\text { Brackish water } \\
\text { mangrove marsh (1) }\end{array}$ & 2 & 4 \\
\hline \multirow{6}{*}{$\begin{array}{l}\text { Culex } \\
\text { sitiens }\end{array}$} & \multirow{6}{*}{$\begin{array}{l}\text { Japanese encephalitis, } \\
\text { Ross River fever and } \\
\text { filariasis }\end{array}$} & Kurunagar & 2011 Sep- & Disused boats (1) & 35 & 20 \\
\hline & & Kurunagar & $\begin{array}{l}2011 \text { Sep-2012 } \\
\text { Jan }\end{array}$ & Used wells (2) & 28 & $2-6$ \\
\hline & & Nainativu & $\begin{array}{l}2011 \\
\text { Aug - } 2012 \text { May }\end{array}$ & Used wells (18) & 24 & $2-39$ \\
\hline & & Sarasalai & 2012 Jan & $\begin{array}{l}\text { Pit near brackish water } \\
\text { mangrove marsh (1) }\end{array}$ & 6 & 12 \\
\hline & & Delft & 2012 March & Pond (5) & 9 & $4-6$ \\
\hline & & $\begin{array}{l}\text { Pannai } \\
\text { bridge }\end{array}$ & 2012 May & $\begin{array}{l}\text { Brackish water } \\
\text { mangrove marsh (1) }\end{array}$ & 5 & 68 \\
\hline $\begin{array}{l}\text { Lutzia } \\
\text { fuscanus }\end{array}$ & $\begin{array}{l}\text { Not a vector but feeds } \\
\text { on larvae of mosquito } \\
\text { vectors }\end{array}$ & Nainativu & 2011 Oct & Used well (1) & 5 & 10 \\
\hline
\end{tabular}


second instar larvae of fresh water-derived Ae aegypti were 0.006 (95\% confidence interval or CI: 0.003 - 0.009) ppm and 0.013 (95\% CI: 0.009 - 0.021) ppm respectively. For $10 \mathrm{ppt}$ brackish water-derived Ae. aegypti, the $\mathrm{LC}_{50}$ and $\mathrm{LC}_{90}$ values were 0.008 (95\% CI: 0.006- 0.011) ppm and 0.012 (95\% CI: $0.010-0.019)$ ppm respectively (Figure 2). These results do not demonstrate a significant difference in sensitivity to BACTIVEC ${ }^{\circledR}$ in the two Ae. aegypti populations.

The effects of $B$. thuringiensis toxin at varying levels of salinity on the survival of fresh and brackish water-derived Ae. aegypti second instar larvae are presented in Figure 3. With increasing salinity in the absence of $B$. thuringiensis toxin, $100 \%$ survival of second instar fresh water-derived Ae. aegypti larvae was recorded at salinity up to $10 \mathrm{ppt}$ and $100 \%$ mortality at 16 ppt with $\mathrm{LC}_{50}$ and $\mathrm{LC}_{90}$ values of 13.9 (95\% CI: 13.1-14.8) and 15.4 (95\% CI: 14.5 - $17.8 \mathrm{ppt}$ respectively at $24 \mathrm{~h}$ post-treatment (Figure 3). Statistical analysis revealed a significant effect of salinity on the lethality of $B$. thuringiensis toxin at each time point $(\mathrm{F}=49.03, \mathrm{P}=0.00$ for $24 \mathrm{~h} ; \mathrm{F}=38.55$, $\mathrm{P}=0.00$ for $48 \mathrm{~h}$ and $72 \mathrm{~h}$ ). However, the brackish water-derived larvae showed $100 \%$ survival up to $12 \mathrm{ppt}$ salinity and $100 \%$ mortality at 18 ppt salinity with $\mathrm{LC}_{50}$ and $\mathrm{LC}_{90}$ values of 15.4 (95\% CI: $14.5-16.2$ ) and 17.1 (95\% CI: 16.2-19.4) ppt respectively at $24 \mathrm{~h}$ posttreatment (Figure 3). Although brackish water-derived Ae. aegypti larvae tended to have higher $\mathrm{LC}_{50}$ and $\mathrm{LC}_{90}$ values for salinity than fresh water-derived Ae. aegypti larvae, the differences are not significant at the $\mathrm{P}=0.5$ level. Statistical analysis however, demonstrated a significant effect of salinity on the toxicity of $B$. thuringiensis in 10 ppt salinity at each time point $(\mathrm{F}=45.38, \mathrm{P}=0.00$ for $24 \mathrm{~h} ; \mathrm{F}=38.68, \mathrm{P}=0.00$ for $48 \mathrm{~h}$ and $72 \mathrm{~h}$ ) with brackish water-derived larvae as in the case of fresh waterderived larvae. In comparison to freshwater-derived Ae aegypti larvae, the brackish water-derived larvae showed significantly enhanced survival at 14 and 16 but not 10 and 12 ppt salinity in the presence of BACTIVEC ${ }^{\circledR}$ at 24,48 and 72 h post-treatment ( $\mathrm{p}<0.05$ by the Student's $\mathrm{t}$ test, Figure 3).

\section{Discussion}

The results show that several different mosquito vectors in coastal areas of northern Sri Lanka can undergo preimaginal development in collections of brackish and saline water in the environment. Larvae of the known malaria vectors, Anopheles varuna and Anopheles barbirostris were detected for the first time in brackish water in Sri Lanka. Although An. culicifacies s.l., the major malaria vector in Sri Lanka, is recognized as a fresh water mosquito, it has been recently reported to undergo preimaginal development in brackish water of up to $4 \mathrm{ppt}$ in eastern Sri Lanka [17]. The present findings show that this is also the case in the northern Jaffna district in Sri Lanka. Culex sitiens is a well-known salinity-tolerant mosquito vector of Japanese encephalitis (JE) virus $[18,19]$ but its role in disease transmission in Sri Lanka has not established. Japanese encephalitis in Sri Lanka is considered to be mainly transmitted by Culex tritaeniorhynchus and Culex gelidus and occurrence of the disease is associated with rice cultivation and piggeries with a high incidence reported from the inland North-central province of the country $[20,21]$. Since pigs are also reared in coastal areas of Jaffna city, there is a potential for $C x$. sitiens to transmit Japanese encephalitis in the Jaffna district.

Although morphologically characterized An. subpictus s.l. was detected to undergo pre-imaginal development in brackish and saline water in this study, its taxonomic status in Sri Lanka is doubtful as molecular characterization of ribosomal DNA revealed that most, if not all morphologically characterized An. subpictus species B in coastal eastern Sri Lanka are in fact An. sundaicus s.l. [22]. Furthermore, results of phylogenetic analysis based on the

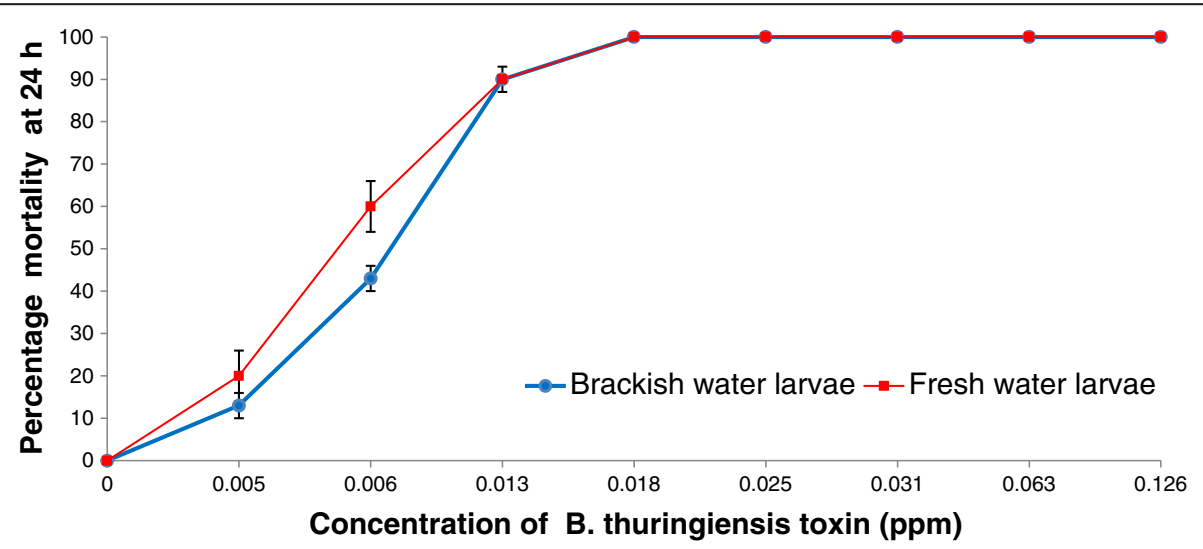

Figure 2 Toxicity of Bacillus thuringiensis israelensis $\mathrm{H}-14$ toxin against fresh and brackish water-derived second instar Ae. aegypti larvae at $\mathbf{2 4} \mathrm{h}$ post-treatment. The bars show standard errors of the mean. 


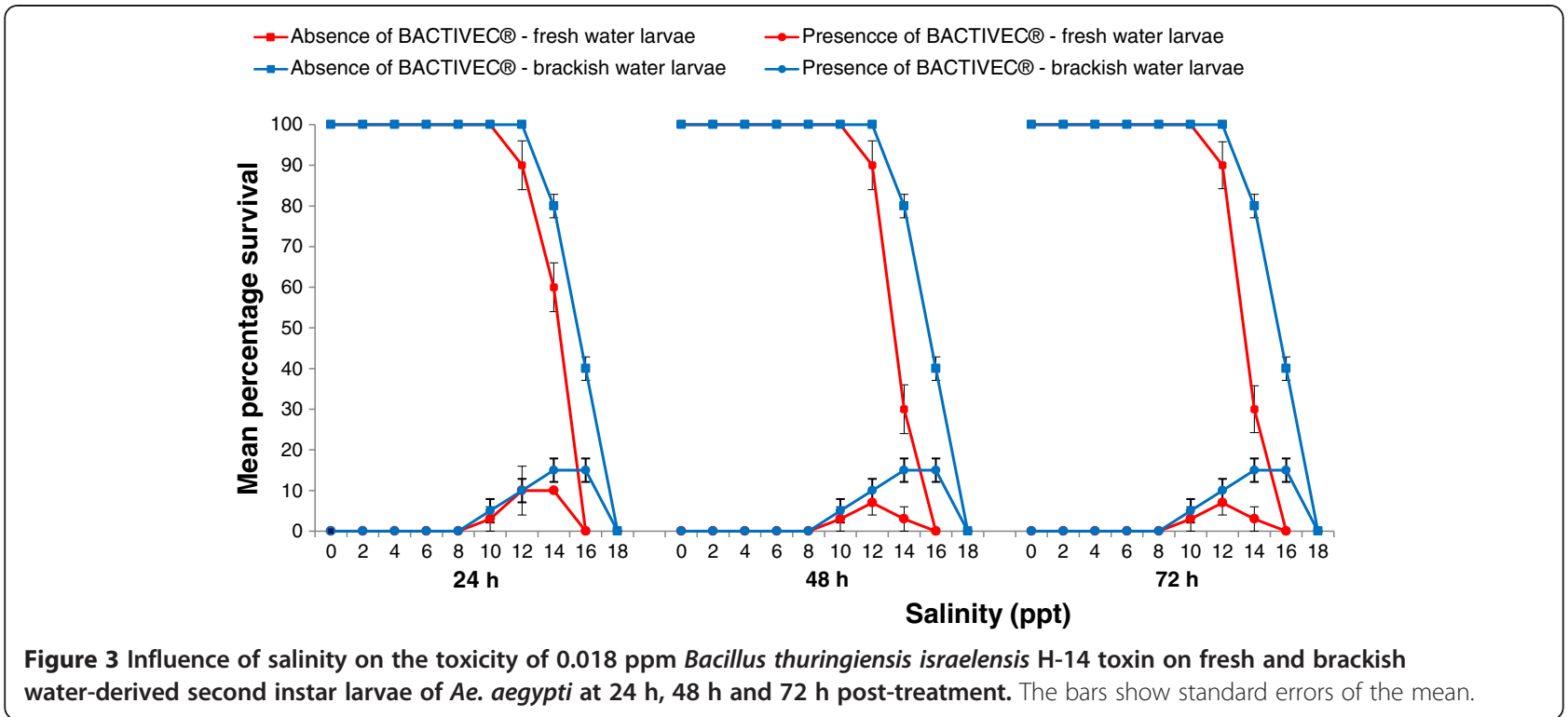

DNA sequence of the internal transcribed spacer-2 (ITS-2) of the ribosomal RNA gene of two An. subpictus s.l. samples collected from Nainativu island during the study period showed genetic similarity to An. sundaicus s.l. (sequence data not shown). Anopheles subpictus species $\mathrm{B} / \mathrm{An}$. sundaicus is predominant in coastal and inland areas of Jaffna peninsula [23] with a higher sporozoite rate than An. culicifacies s.l. [24]. Therefore, considering the well-known salinity tolerance and vector potential of An. sundaicus s.l. elsewhere in Asia [19], its probable presence in coastal and inland areas of the Jaffna peninsula indicates a potential for malaria transmission. Brackish water development of Ae. aegypti and Ae. albopictus has recently been demonstrated in the Jaffna and Batticaloa districts of Sri Lanka [10]. Ae. aegypti and Ae. albopictus are well known vectors of dengue and chikungunya. Aedes albopictus can also transmit the JE virus [19]. The present findings confirm that the two arboviral vectors are able to undergo pre-imaginal development in brackish water collections in the environment. An interesting observation is that the predatory mosquito Lutzia fuscanus which readily feed on other mosquito larvae, especially Aedes larvae (Jude, P.J., Paramsothy, S, Thavaranjith, A.C., Ramasamy, R., Surendran, S.N.; unpublished data), develops in the same brackish water as its prey in Nainativu island. This is the first report of $L$. fuscanus larvae in brackish water in Sri Lanka. Lutzia fuscanus is generally regarded to undergo pre-imaginal development in ground-water habitats with a high organic content [25]. The results suggest the L. fuscanus may naturally limit the pre-imaginal development of mosquito vectors in brackish water habitats in the Jaffna district.

A previous study that investigated the salinity tolerance of Ae. aegypti and Ae. albopictus in Jaffna district showed that the $\mathrm{LC}_{50}$ values for first and third instar fresh water-derived larvae of Ae. aegypti developing into adults were 11.9 and 15.5 ppt salinity respectively [10], consistent with the $\mathrm{LC}_{50}$ of 13.9 ppt salinity observed with fresh water-derived second instar larvae at $24 \mathrm{~h}$ in the present study. The corresponding values for fresh water-derived Ae. albopictus were reported to be 13.0 and $16.0 \mathrm{ppt}$ in an earlier study [10]. The range of salinities observed in the habitats where Ae. aegypti and Ae. albopictus were collected in the present study are consistent with previous [10] and present laboratory results for salinity tolerance of their larvae .

The present study shows that the salinity levels that Ae. aegypti and Ae. albopictus larvae are able to tolerate in the environment has a small but significant impact on reducing the toxicity of $B$. thuringiensis toxin, which is commonly used for larval source reduction in Sri Lanka. Furthermore, the differential survival and $\mathrm{LC}_{50}$ and $\mathrm{LC}_{90}$ values of fresh and brackish water-derived larvae tend to suggest that Ae. aegypti may be able to adapt to salinity in its environment. The results indicate that Ae. aegypti derived from brackish water habitats may be better able to withstand the toxicity of BACTIVEC ${ }^{\circledR}$ in more brackish waters. A previous study on the effectiveness of two commercial formulations of $B$. thuringiensis toxin for the control of salinity-tolerant malaria vector Anopheles aquasalis at different salt concentrations revealed an increase in the $\mathrm{LC}_{50}$ for $B$. thuringiensis at higher salt concentrations [26]. Our results suggest that crystal formulation of $B$. thuringiensis toxin sprayed in the more brackish water pre-imaginal development sites of Ae. aegypti as a source reduction strategy in coastal zones may be less effective than in fresh water habitats. The nature of the interaction between salinity and the tested commercial formulation of 
B. thuringiensis toxin $\left(\right.$ BACTIVEC $\left.^{\circledR}\right)$ is not known. This could be a consequence of the effect of salinity on the toxin formulation itself or to an effect on mosquito physiology that modulates the response to the toxin. Further investigations are needed to clarify the two possibilities.

Many countries have used B. thuringiensis for malaria and dengue vector control with varying degrees of success [27-30]. However, the effect of salinity on the activity of $B$. thuringiensis toxin against larvae of other mosquito vector species e.g. Ae. albopictus and An. sundaicus s.l. in brackish and saline water also merits detailed investigation. It is possible that other commercial formulations of B. thuringiensis toxin may behave differently if the effect is due to salt on the toxin formulation itself and not larval physiology.

\section{Conclusion}

The present study identifies several mosquito vectors of human disease that undergo pre-imaginal development in brackish or saline waters in coastal areas of the Jaffna district in northern Sri Lanka. Salt has a small but significant negative impact on the toxicity of $B$. thurigiensis to Ae. aegypti larvae at salinity levels where larvae are found in the environment, and this has to be taken into consideration for its use as a larvicide.

\section{Competing interests}

The authors declare that they have no competing interests.

\section{Authors' contribution}

SNS, RR and MS conceived the study. PJJ and SK performed field studies, T, PJJ and GS performed laboratory studies. SNS, TT, and MS did analysis. SR created the images. SNS and RR wrote the manuscript. All authors read and approved the manuscript.

\section{Author details}

'Department of Zoology, Faculty of Science, University of Jaffna, Jaffna 40000, Sri Lanka. ${ }^{2}$ Department of Chemistry, Faculty of Science, University of Jaffna, Jaffna, Sri Lanka. ${ }^{3}$ Department of Pathology, Faculty of Medicine, University of Jaffna, Jaffna, Sri Lanka. ${ }^{4}$ Department of Geography, Faculty of Arts, University of Jaffna, Jaffna, Sri Lanka. ${ }^{5}$ Institute of Health Sciences, Universiti Brunei Darussalam, Gadong, BE 1410, Brunei Darussalam.

Received: 9 August 2012 Accepted: 16 November 2012

Published: 22 November 2012

\section{References}

1. World Health Organization: Denque Guidelines for Diagnosis, Treatment, Prevention and Control. 2011. WHO/HTM/NTD/DEN/2009.1 http://whqlibdoc.who.int/publications/2009/9789241547871_eng.pdf (Accessed July 12, 2011).

2. Weaver SC, Reisen WK: Present and future arboviral threats. Antiviral Res 2010, 85:328-345.

3. Cavrini F, Gaiban P, Pierro AM, Rossini G, Landini MP, Sambri V: Chikungunya: an emerging and spreading arthropod-borne viral disease. $J$ Infect Dev Ctries 2009, 3:744-752.

4. Epidemiology Unit: Ministry of Healthcare and Indigenous Medicine, Sri Lanka. 2012. http://www.epid.gov.lk/web/index.php?option=com_casesand deaths\&ltemid=448\&lang=en\#.

5. Surendran SN, Kannathasan S, Kajatheepan A, Jude PJ: Chikungunya-type fever outbreak: some aspects related to this new epidemic in Jaffna district, northern Sri Lanka. Trop Med Health 2007, 35:249-252.
6. Anti-Malaria Campaign. Sri Lanka; 2012. http://www.malariacampaign.gov.lk/ Precentation/Home.aspx.

7. Anti-Filarial Campaign. Sri Lanka; 2012. http://203.94.76.60/departmnt/ dgfilaria.htm.

8. Epidemiology Unit: Ministry of Healthcare and Indigenous Medicine. Sri Lanka; 2012. http://www.epid.gov.lk/web/index.php? option=com_content\&view=article\&id=146\&ltemid=459\&lang=en

9. Boisvert M: Utilization of Bacillus thuringiensis var. israelensis (Bti)-based formulations for the biological control of mosquitoes in Canada. In Pacific Rim Conference on the Biotechnology of Bacillus thuringiensis and its Environmental Impact. 6th edition. Edited by Cõtê JC, Otvos IS, Schwartz JL Vincent C. 2005:87-93.

10. Ramasamy R, Surendran SN, Jude PJ, Dharshini S, Vinobaba M: Larval development of Aedes aegypti and Aedes albopictus in peri-urban brackish water and its implications for transmission of arboviral diseases. PLoS Negl Trop Dis 2011, 5(11):e1369.

11. Surendran SN, Jude PJ, Thabothiny V, Raveendran S, Ramasamy R: Pre-imaginal development of Aedes aegypti in brackish and fresh water urban domestic wells in Sri Lanka. J Vect Ecol 2012, in print.

12. Ramasamy R, Surendran SN: Global climate change and its potential impact on disease transmission by salinity-tolerant mosquito vectors in coastal zones. Front Physiol (Systems Biology) 2012, 3:198. doi:10.3389/ fphys.2012.00198.

13. Rajasooriyar LD, Mathavan V, Dharmagunewardene HA, Nandakumar V: Groundwater quality in the Valigamam region of the Jaffna Peninsula, Sri Lanka. In Sustainable Groundwater Development. Edited by Hiscock KM, Rivett MO, Davison RM. London: Special publications 193, Geological Society; 2002:181-197.

14. Amerasinghe FP: A guide to the identification of the anopheline mosquitoes (Diptera: Culicidae) of Sri Lanka. I Adult females. Cey I Sci (Bio Sci) 1990, 21:1-16.

15. Rattanarithikul R, Harbach RE, Harrison BA, Panthusiri P, Jones JW, Coleman RE: Illustrated keys to the mosquitoes of Thailand. II. Genera Culex and Lutzia. Southeast Asian J Trop Med Public Health 2005, 36(Suppl 2):1-97.

16. Rueda LM: Pictorial keys to the identification of mosquitoes (Diptera: Culicidae) associated with denque virus transmission. (Zootaxa, 589). Auckland, New Zealand: Magnolia Press; 2004:42-49.

17. Jude PJ, Dharshini S, Vinobaba M, Surendran SN, Ramasamy R: Anopheles culicifacies breeding in brackish waters in Sri Lanka and implications for malaria control. Malar J 2010, 9:106.

18. Vythilingam I, Tan SB, Krishnasamy M: Susceptibility of Culex sitiens to Japanese encephalitis virus in peninsula Malaysia. Trop Med Int Health 2002, 7:539-540

19. Walter Reed Biosystematics Unit. 2012. http///wrbu.org/command_aors_MQ.html.

20. Peiris JSM, Amerasinghe FP, Amerasinghe PH, Ratnayake CB, Karunaratne SHPP, Tsai TF: Japanese encephalitis in Sri Lanka - the study of an epidemic: vector incrimination, porcine infection and human disease. Trans R Soc Trop Med Hyg 1992, 86:307-313.

21. Peiris JSM, Amerasinghe FP, Arunagiri CK, Perera LP, Karunaratne SHPP, Ratnayake CB, Kulatilaka TA, Abeysinghe MRN: Japanese encephalitis in Sri Lanka: comparison of vector and virus ecology in different agro-climatic areas. Trans R Soc Trop Med Hyg 1993, 87:541-548.

22. Surendran SN, Singh OP, Jude PJ, Ramasamy R: Genetic evidence for the presence of malaria vectors of the Anopheles sundaicus complex in Sri Lanka with morphological characteristics attributed to Anopheles subpictus species B. Malar J 2010, 9:343.

23. Kannathasan $\mathrm{S}$, Antonyrajan A, Srikrishnaraj KA, Karunaratne SHPP, Karunaweera ND, Surendran SN: Studies on prevalence of anopheline species and community perception of malaria in Jaffna district, Sri Lanka. J Vector Borne Dis 2008, 45(3):231-239.

24. Thevarajah C, Rajendram GF: Malaria transmission by Anopheles species in Jaffna peninsula. Proc Jaffna Sci Assoc 1995, 4:20.

25. Walter Reed Biosystematics Unit: Walter Reed Biosystematics Unit. 2012. http://wrbu.si.edu/generapages/lutzia.htm.

26. Osborn FR, Herrera MJ, Gomez CJ, Salazar A: Comparison of two commercial formulation of Bacillus thuringiensis var. israelensis for the control of Anopheles aquasalis (Diptera: Culicidae) at three salt concentrations. Mem Inst Oswaldo Cruz, Rio de Janeiro 2007, 102:69-72.

27. Nyarango PM, Gebremaeskel T, Mebrahtu G: A steep decline of malaria morbidity and mortality trends in Eritrea between 2000 and 2004: the effect of combination of control methods. Malar J 2006, 5:33. 
28. Lee YW, Zairi J: Field evaluation of Bacillus thuringiensis $\mathrm{H}-14$ against Aedes mosquitoes. Trop Biomed 2006, 23:37-44.

29. Russell TL, Brown MD, Purdie DM: Efficacy of VectoBac (Baccillus thuringiensis variety israelensis) formulations for mosquito control in Australia. J Econ Entomol 2003, 96:1786-1791.

30. Lee VJ, Ow S, Heah H, Tan MY, Lam P, Ng LC, Lam-Phua SG, Imran AQ, Seet B: Elimination of malaria risk through integrated combination strategies in a tropical military training island. Am J Trop Med Hyg 2010,

82(6):1024-1029.

doi:10.1186/1756-3305-5-269

Cite this article as: Jude et al: Salinity-tolerant larvae of mosquito

vectors in the tropical coast of Jaffna, Sri Lanka and the effect of salinity on the toxicity of Bacillus thuringiensis to Aedes aegypti larvae. Parasites \& Vectors 2012 5:269.

\section{Submit your next manuscript to BioMed Central and take full advantage of:}

- Convenient online submission

- Thorough peer review

- No space constraints or color figure charges

- Immediate publication on acceptance

- Inclusion in PubMed, CAS, Scopus and Google Scholar

- Research which is freely available for redistribution 